\title{
БИОЛОГИЧЕСКИЕ НАУКИ
}

\section{РICT МIЖВУЗЛІВ TRITICUM AESTIVUM L. TА ПРОДУКТИВНІСТЬ РОСЛИН ЗА УМОВ ПОСУХИ}

Жук Ольга Іванівна

доктор біологічних наук, науковий співробітник

Інститут фізіологї рослин $i$ генетики НАН України, 03022, вулиця Васильківська 31/17, Україна, місто Київ

Анотація. Показано, що дія посухи у фазі виходу у трубку рослин пшениці м'якої озимої (Triticum aestivum L.) сортів Наталка, Донецька 48, Райгородка, Придніпровська зупиняла ріст міжвузлів пагона. Ріст міжвузлів і колоса після посухи був більш значним у сортів Наталка і Донецька 48, ніж у сорту Райгородка. Розміри колоса у бічних пагонах зменшувались у всіх сортів, що спричинило зменшення їх зернової продуктивності. Сорти Наталка i Придніпровська виявили вищу стійкість до посухи порівняно 3 сортами Донецька 48 і Райгородка, що дозволило сформувати більшу кількість і масу зерен. Зменшення розмірів міжвузлів у сорту Райгородка спричинило зниження продуктивності рослин. Дослідження росту міжвузлів рослин озимої пшениці за впливу природної посухи у фазі виходу у трубку дозволяє передбачати їх врожайність в несприятливих $\mathrm{i}$ нестабільних умовах навколишнього середовища.

Ключові слова: пшениця, міжвузля, колос, зерно, посуха.

\section{INTERNOD GROWTH TRITICUM AESTIVUM L. AND PLANTS PRODUCTIVITY UNDER DROUGHT CONDITIONS}

Olga Zhuk

Doctor of biological sciences, scientist Institute of Plant Physiology and Genetics NAS of Ukraine, 03022, Vasylkyvska st. 31/17, Ukraine, Kyiv 
Abstract. It is shown that drought caused the delaying the growth of internodes in the booting phase in soft winter wheat plants (Triticum aestivum L.) cultivars Natalka, Donecka 48, Raygorodka, Pridniprovska. The growth of internodes and ear were more significant in cultivars Natalka, Donecka 48 then in cultivar Raygorodka after drought. The ear size and grain productivity decreased in tillers of all cultivars. It was shown that cultivars Natalka and Pridniprovska had higher drought tolerance, quantity and mass of grains than in cultivars Donecka 48 and Raygorodka. Decreasing size of internodes caused the reducing of plant productivity in cultivar Raygorodka. Investigation of internodes growth in the booting phase under the natural drought conditions allows to predict yield of winter wheat plants under the unfavorable and unstable environmental conditions.

Key words: wheat, internode, ear, grain, drought.

Зростання попиту на продукти харчування у світі обумовлює необхідність підвищення врожайності продовольчих культур [1]. Пшениця м'яка озима в Україні використовується як продовольча, фуражна та технічна культура, що спонукає селекціонерів до збільшення кількості і різноманіття іiі сортів, підвищення їх стійкості до несприятливих умов навколишнього середовища [2]. Посуху відносять до найважливіших чинників, які впливають на реалізацію продуктивного потенціалу рослин пшениці [3]. В Україні природну посуху в окремі роки відзначали у фазі виходу у трубку рослин пшениці озимої, підчас якої відбувається ріст стебла, міжвузлів, листків, колоса і його компонентів, визначається кількість розвинених квіток [4].

Формування оптимальної архітектоніки рослин здійснюється через процеси макроморфогенезу, які регулюються геномом, модифікуються факторами навколишнього середовища $[5,6]$. Ріст рослин і їх врожайність тісно пов'язані між собою i регулюються відповідними генами, які були ідентифіковані і названі “intrinsic yield genes”( $\mathrm{IYG}_{\mathrm{s}}$ ) [5]. Ці гени утворюють функціональні класи, що керують відповідними процесами, метаболічними потоками. Ріст рослин регулюється онтогенетичною програмою, що має 
принаймні два рівня координації [7]. Розміри окремих органів визначаються взаємозалежними процесами проліферації і розтягнення окремих клітин. Здатні до проліферації клітини пагонів пшениці локалізовані у інтеркалярних та апікальних меристемах, що мають обмежений період існування у часі і просторі [8, 9]. Дефіцит води, мінерального живлення, екстремальні температурні умови спричиняють затримку або повну зупинку поділу клітин, що призводить до зменшення кількості новоутворених клітин і в кінцевому випадку розмірів компонентів стебла, репродуктивних органів та врожаю рослин пшениці [10, 11]. Оптимізація умов існування рослин після повної втрати функціональної здатності меристем дозволяє збільшувати розміри утворених ними органів за рахунок розтягнення клітин лише у певних межах і не компенсує повною мірою втрати чисельності клітин.

Дефіцит води у грунті сприймають корені і транспортують сигнал про зміну водного статусу до пагонів по ксилемі [10]. Одним 3 головних компонентів сигналу є абсцизова кислота, що синтезується у клітинах зони розтягнення коренів та листках. Останній крок біосинтезу абсцизової кислоти каталізує фермент альдегідоксидаза, активність якого зростає в умовах водного дефіциту. Два рецептори, що сприймають сигнал АБК, локалізовані на внутрішній стороні плазмалеми і один - на зовнішній. Головною відповіддю рослин мезофітів на посуху є збільшення опору продихів або їх закривання для мінімізації втрат води через транспірацію. Одночасно гальмується фотосинтетичний метаболізм, що залежить від надходження вуглекислоти 3 повітря і є головним джерелом вуглеводів для росту та життєдіяльність рослин. Наслідком дефіциту вуглеводів стає гальмування росту, зменшення площі листкової поверхні за рахунок скидання частини листків. У пшениці вуглеводи здатні накопичуватись у верхніх міжвузлях підчас розтягнення клітин і служать резервом та джерелом ресурсів для зернівок у фазах формування та наливу зерна, що набувають особливого значення за умов втрати функціональної здатності фотосинтетичним апаратом у період старіння листків. Розміри міжвузлів та швидкість їх росту обумовлюють величину запасів вуглеводів, що 
стають критичними в умовах посухи, дефіциту елементів мінерального живлення, втрати листкового апарату [11].

Метою роботи було дослідження впливу природної посухи на ріст міжвузлів, колоса та продуктивність рослин пшениці м’якої озимої.

Рослини пшениці м’якої озимої (Triticum aestivum L.) сортів Наталка, Донецька 48, Райгородка, Придніпровська вирощували в умовах дрібноділянкового досліду у 2017 році у Київській області за оптимального живлення, що становило $\mathrm{N}_{120} \mathrm{P}_{120} \mathrm{~K}_{120}$ за діючою речовиною. Для удобрення використовували промислово виготовлене добриво нітроамофоску. Половинну норму добрив вносили перед посівом, решту - при підживленні у фазах кущіння та цвітіння. Грунт сірий лісовий. Розмір облікової ділянки для кожного сорту становив 1 м², повторність чотириразова. Природну посуху відзначено у фазі виходу у трубку, яка тривала 14 діб. Протягом періоду від початку фази виходу у трубку до фази формування зернівки через однакові проміжки часу відбирали по 15 рослин, у яких вимірювали довжину міжвузлів, довжину колоса у мм, площу листкової поверхні усієї рослини у см². Відбори 1-4 проводили у фазі виходу у трубку, 5-колосіння-цвітіння, 6-8-наливу та молочної стиглості зерна. Після дозрівання рослин визначали масу та кількість зерен у колосах та рослинах. Результати оброблені статистично за допомогою ANOVA.

Встановлено, що ріст трьох нижніх міжвузлів пшениці сорту Наталка у головному та бічних пагонах завершувався до початку росту двох верхніх у період дії посухи (рис.1 a, б, в). Ріст четвертого від низу стебла міжвузля у сорту Наталка завершувався раніше ніж останнього п’ятого міжвузля, що утримувало колос. Розмір четвертого міжвузля головного пагона був більшим порівняно з бічними пагонами, однак розмір п’ятого міжвузля у всіх пагонів був близьким. У пшениці сорту Донецька 48 ріст трьох нижніх міжвузлів також припинявся підчас посухи, а після їі припинення продовжувався ріст двох верхніх міжвузлів, однак їх кінцеві розміри у бічних пагонах зменшувались порівняно з головним пагоном (рис.1 г, д, ж). Ріст верхніх міжвузлів пагонів пшениці сорту Донецька 48 завершувався одночасно у головному та бічних 
пагонах. Найбільші відмінності у розмірах п’ятого міжвузля у цього сорту відзначено для головного та бічних пагонів.
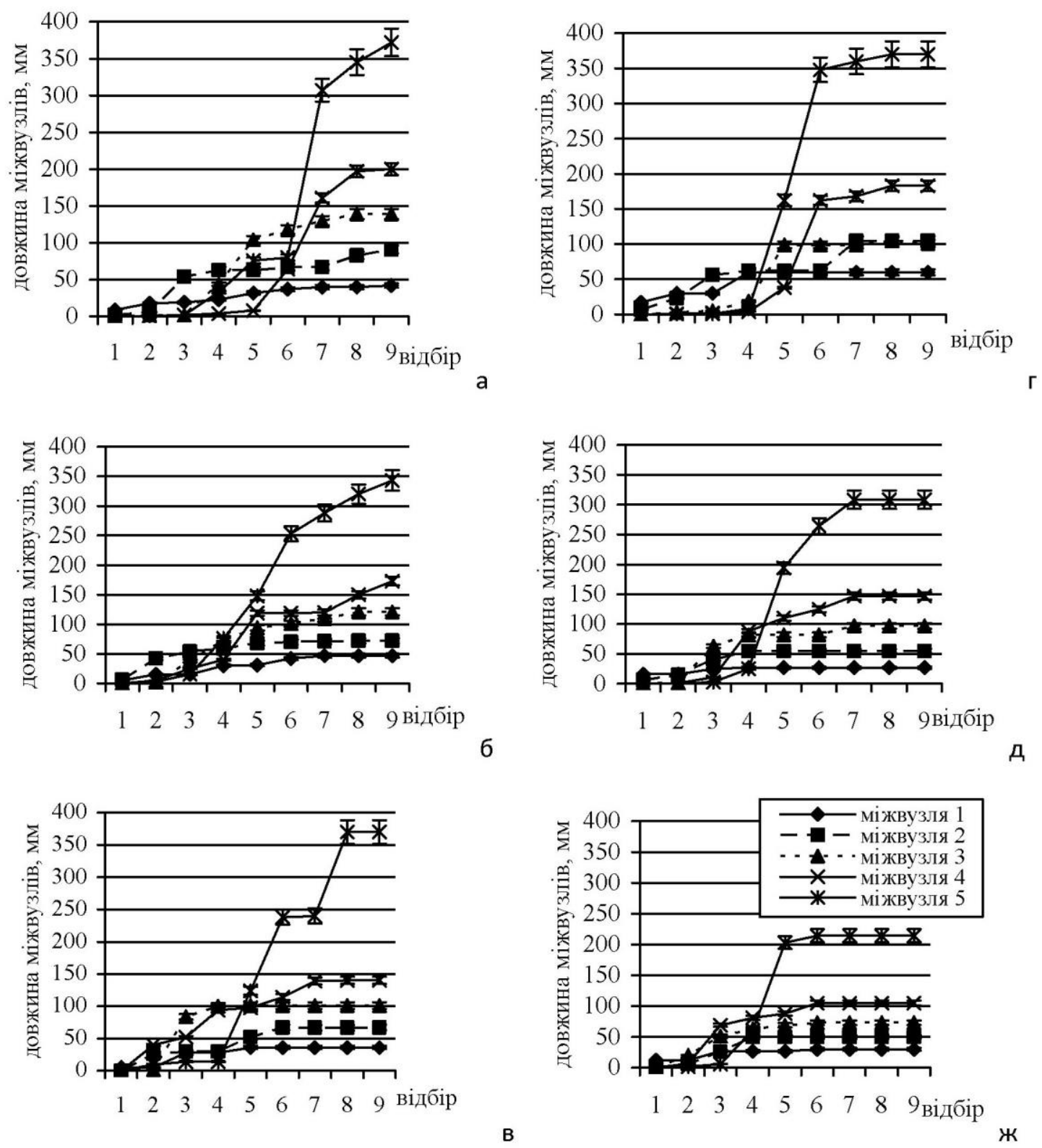

Рис. 1. Ріст міжвузлів пшениці сорту Наталка (а-головний пагін, б-1бічний, в-2 бічний пагін) сорту Донецьька 48 (2- головний пагін, д-1-бічний, ж2-бічний пагін)

У пшениці сорту Райгородка розміри міжвузлів у головного і бічних пагонів відрізнялись незначно, однак ріст п’ятого міжвузля у бічних пагонах тривав довше порівняно з головним (рис.2 а, б, в). Розмір верхнього міжвузля пагонів пшениці сорту Райгородка був меншим ніж у сортів Наталка і Донецька 48. Розміри трьох нижніх міжвузлів у головному і бічних пагонах цього сорту були близькими. У пшениці сорту Придніпровська ріст трьох нижніх міжвузлів 
завершувався одночасно у головному та бічних пагонах, їх розміри збільшувались від низу до верху стебла (рис. 2 г, д, ж).

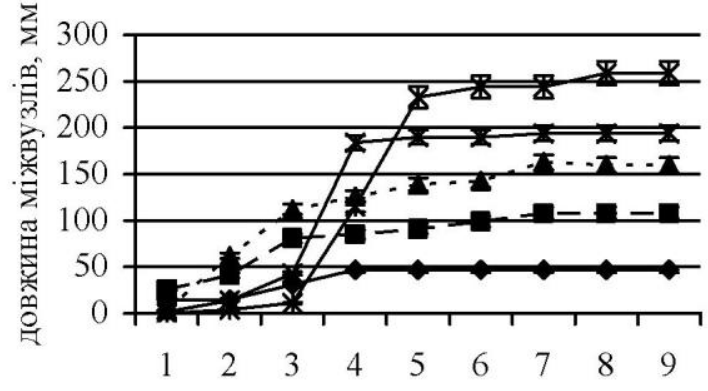

відбір

a
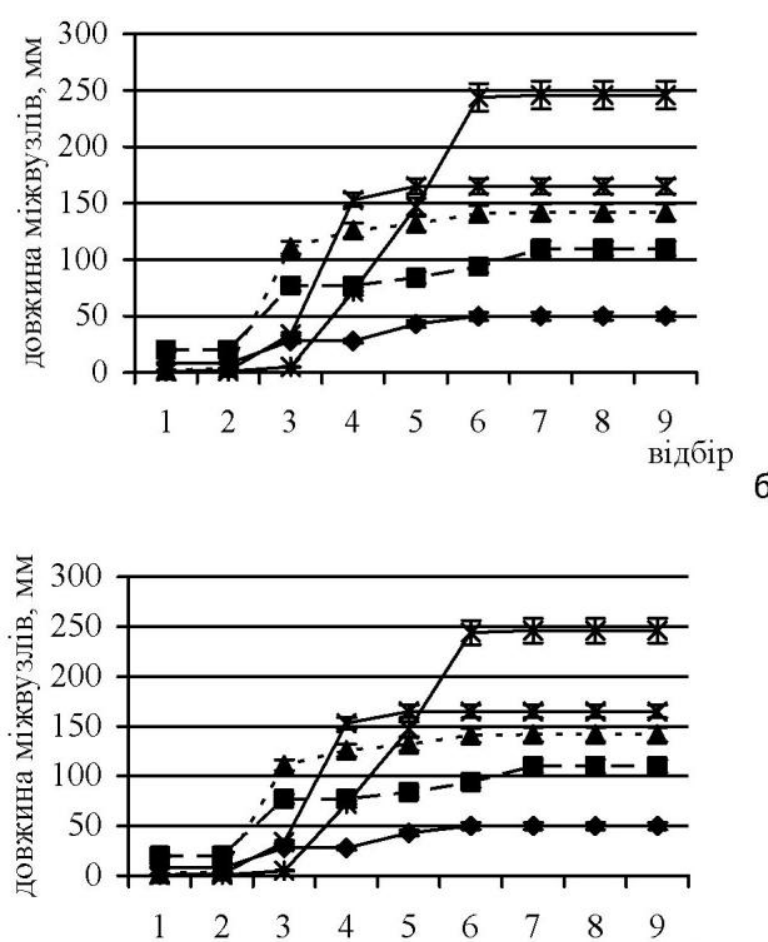

відбір
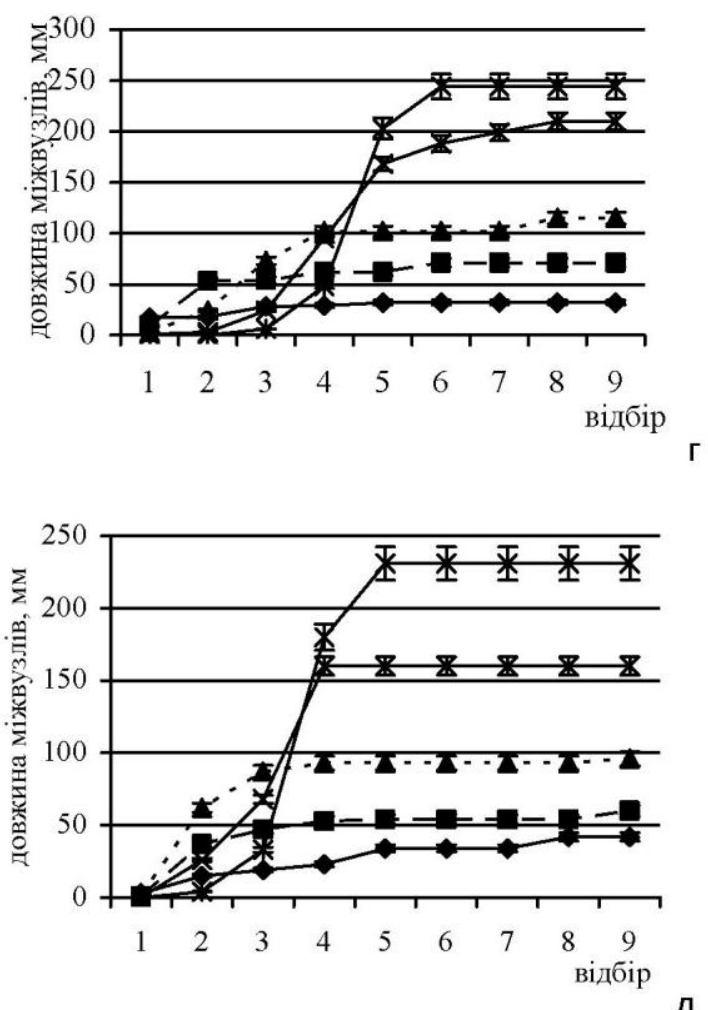

д

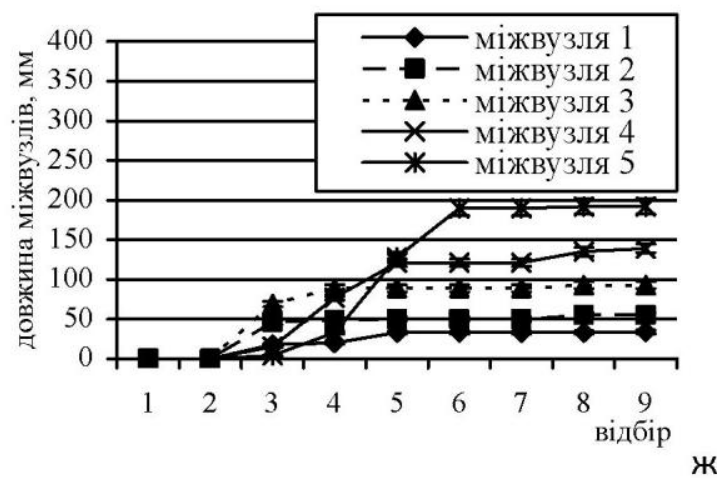

Рис. 2. Ріст міжвузлів рослин пшениці озимої сортів Райгородка (аголовний пагін, б-1-бічний пагін, в-2-бічний пагін) Придніпровська( г-головний пагін, д- 1-бічний пагін, ж-2-бічний пагін) .

Розміри двох верхніх міжвузлів пшениці сорту Придніпровська зменшувались від головного до бічних пагонів. Ріст колоса головного та двох бічних пагонів пшениці сортів Наталка, Донецька 48, Придніпровська, Райгородка затримувався у період дії посухи і відновлювався після іiі припинення, однак розміри колосів бічних пагонів зменшувався у всіх сортів, а ïx ріст починався пізніше порівняно з колосом головного пагона (рис.3). 

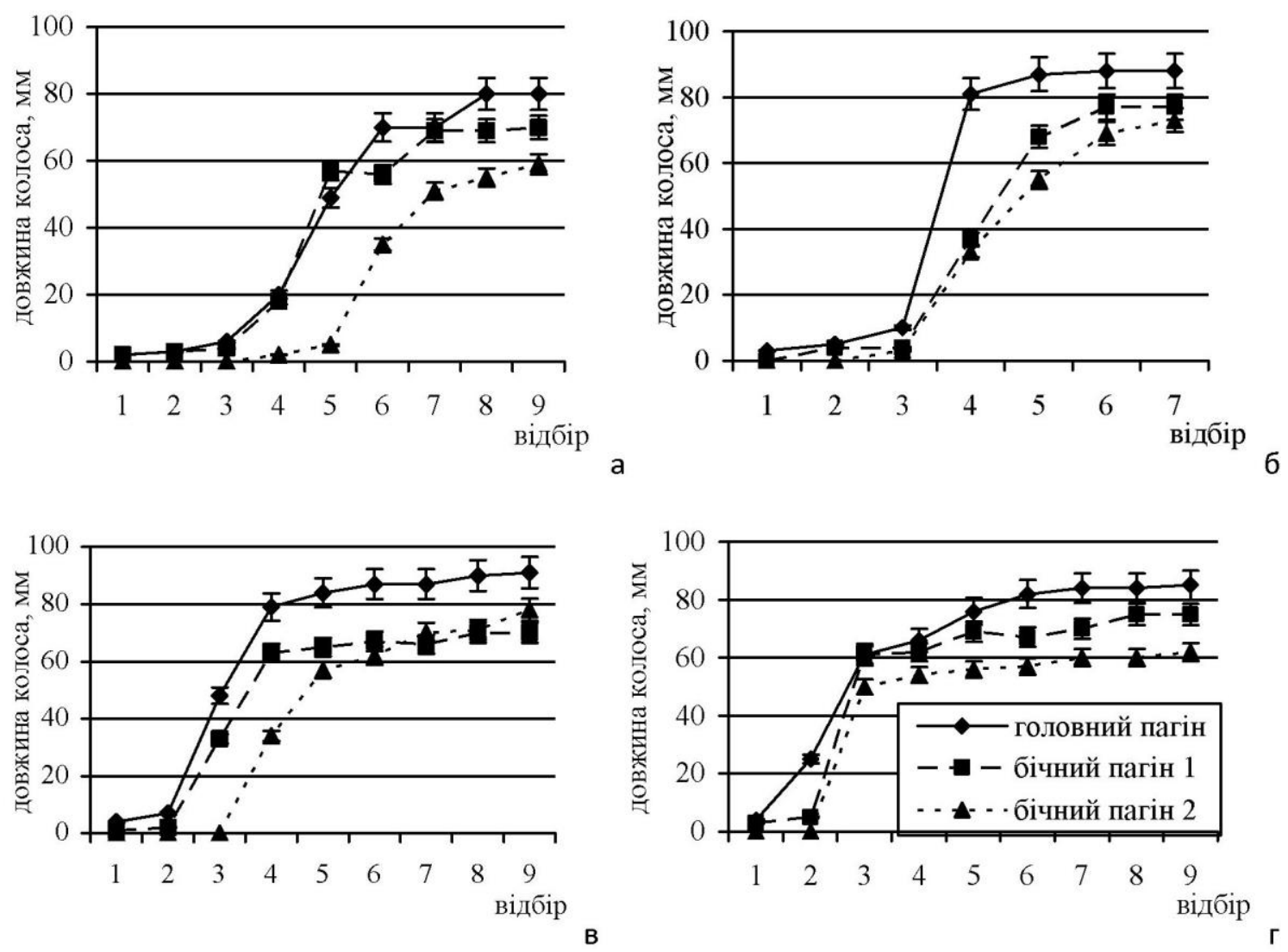

Рис. 3. Ріст колоса пшениці сортів Наталка (а), Донецька 48 (б), Придніпровська (в), Райгородка (2).

Збільшення площі листкової поверхні у рослин пшениці підчас дії посухи уповільнювалось, особливо у сортів Придніпровська і Наталка (рис.4). Після відновлення водопостачання рослин площа листків зростала лише у пшениці сорту Донецька 48 за рахунок відростання бічних пагонів, які створювали конкуренцію за ресурси з продуктивними пагонами.

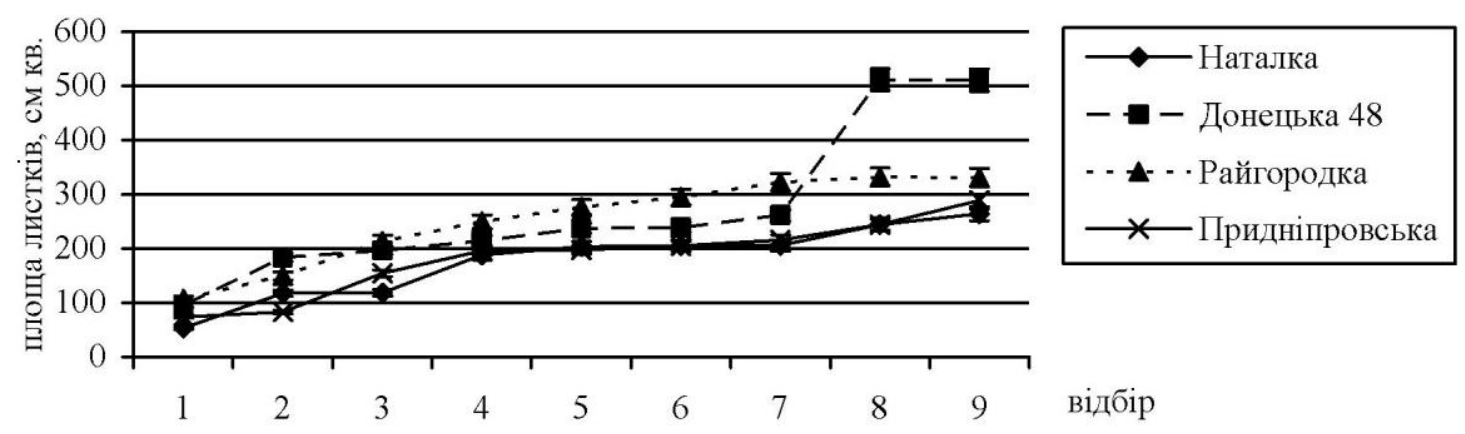

Рис.4. Площуа листкової поверхні рослин пшениџฺ сортів Наталка, Донецька 48, Райгородка, Придніпровська 
Після дії природної посухи у фазі виходу у трубку найзначніше зменшувалась озерненість колоса і маса зерен головного та бічних пагонів у пшениці сорту Райгородка і найменше у сорту Придніпровська (табл. 1.).

Таблиця 1.

Маса та кількість зерен у колосі пшениці сортів Наталка, Донецька 48, Придніпровська, Райгородка

\begin{tabular}{|l|l|l|l|l|l|l|l|l|}
\hline \multirow{2}{*}{ Сорт } & \multicolumn{3}{|l|}{ Маса зерен у колосі, г } & \multicolumn{3}{l|}{$\begin{array}{l}\text { Кількість зерен у колосі, } \\
\text { шт. }\end{array}$} \\
\cline { 2 - 9 } & гол. к. & б.к.1 & б.к.2 & б.к.3 & $\begin{array}{l}\text { гол. } \\
\text { к. }\end{array}$ & б.к.1 & б.к.2 & б.к.3 \\
\hline Наталка & $1,96 \pm$ & $1,41 \pm$ & $0,91 \pm$ & $0,55 \pm$ & $42 \pm 2$ & $25 \pm 3$ & $20 \pm 3$ & $17 \pm 3$ \\
& 0,4 & 0,3 & 0,3 & 0,2 & & & & \\
\hline Донецька 48 & $1,75 \pm$ & $1,15 \pm$ & $0,46 \pm$ & $0,33 \pm$ & $43 \pm 3$ & $30 \pm 5$ & $20 \pm 4$ & $16 \pm 5$ \\
& 0,6 & 0,5 & 0,3 & 0,5 & & & & \\
\hline $\begin{array}{l}\text { Придніпров- } \\
\text { ська }\end{array}$ & $2,05 \pm$ & $1,16 \pm$ & $0,83 \pm$ & $0,56 \pm$ & $45 \pm 3$ & $29 \pm 2$ & $23 \pm 4$ & $20 \pm 3$ \\
\hline Райгородка & 0,3 & 0,2 & 0,3 & 0,2 & & & & \\
& $0,18 \pm$ & $0,99 \pm$ & $0,47 \pm$ & $0,34 \pm$ & $35 \pm 3$ & $26 \pm 2$ & $16 \pm 3$ & $13 \pm 4$ \\
\hline
\end{tabular}

Кількість зерен на рослину була найбільшою у пшениці сорту Придніпровська, а маса зерен - у сорту Наталка (табл. 2). Рослини пшениці сорту Райгородка сформували найменшу кількість та масу зерен на рослину.

Таблиця 2.

Маса та кількість зерен у рослин пшениці сортів Наталка, Донецька 48, Придніпровська, Райгородка

\begin{tabular}{|l|l|l|}
\hline \multicolumn{1}{|c|}{ Сорт } & $\begin{array}{l}\text { Маса зерен на рослину, } \\
\Gamma\end{array}$ & $\begin{array}{l}\text { Кількість зерен на } \\
\text { рослину, шт. }\end{array}$ \\
\hline Наталка & $4,83 \pm 0,3$ & $104 \pm 3$ \\
\hline Донецька 48 & $3,46 \pm 0,5$ & $104 \pm 4$ \\
\hline Придніпровська & $4,60 \pm 0,4$ & $117 \pm 4$ \\
\hline Райгородка & $2,98 \pm 0,3$ & $90 \pm 4$ \\
\hline
\end{tabular}

Таким чином, підчас природної посухи у фазі виходу у трубку рослин пшениці озимої затримувався ріст усіх елементів пагона. Після ï припинення відновлювався ріст двох верхніх міжвузлів і колоса у всіх вивчених сортів пшениці, а ріст листкової поверхні лише у пшениці сорту Донецька 48. Найбільш слабостійким до умов посухи був сорт пшениці Райгородка. Рослини 
цього сорту сформували найменші верхні міжвузля, колос, що могло стати головною причиною зменшення їх продуктивності. Відновлення росту листкової поверхні у пшениці сорту Донецька 48 відбувалось за рахунок бічних пагонів і призводило до конкуренції за асиміляти між непродуктивними i продуктивними пагонами і стало причиною зменшення маси зернівок. У рослин пшениці сорту Придніпровська розміри колоса головного та бічних пагонів були близькими, що дозволило їм закласти найбільшу серед досліджених сортів кількість зерен, однак зменшення розмірів верхніх міжвузлів у бічних пагонах не дозволило у повній мірі забезпечити необхідними ресурсами зернівки, що зменшило їх кінцеву масу. Відомо, що розміри пагонів та площа листкової поверхні продуктивних пагонів безпосередньо впливають на забезпечення репродуктивних органів та насіння асимілятами та іншими необхідними ресурсами [4, 5]. Встановлено, що недостатнє водозабезпечення рослин пшениці у фазу колосіння-цвітіння знижувало їх продуктивність переважно через втрату фертильності пилку, порушення процесів запилення та запліднення [12]. Цю фазу вважали найбільш критичною для формування врожаю пшениці. Проведені дослідження свідчать, що дія грунтової посухи у фазі виходу в трубку на рослини пшениці озимої затримувала ріст міжвузлів і колоса, а його відновлення після завершення посухи відбувалось лише у верхніх міжвузлях і колосі з неоднаковою інтенсивністю у різних сортів, що впливало на врожай рослин пшениці озимої. Дослідження впливу природної посухи на ростові процеси у пагоні пшениці озимої у фазі виходу у трубку дозволяє оцінити іiі вплив на реалізацію потенційної продуктивності рослин у різних сортів.

\section{Література}

1. Edgerton M.D. Increasing crop productivity to meet global needs for feed, food, and fuel // Plant Physiol.-2009.-v.149.-P.7-13.

2. Литвиненко М.А. Селекція і насінництво: двоєдине ціле // Насінництво.2012.- №7.-C.1- 4. 
3. Barnabas B. Jager K., Feher A The effect of drought and heat stress on reproductive processes in cereals //Plant. Cell Environ. -2008.- v. 31.- P. 11-38.

4. Weng X. Wang L., Hu J., Du H., Xu C., Xing Y. Xiao J., Zhang Q.Grain number, plant height and heading date 7 is a central regulator of growth, development and stress response // Plant Physiol.-2014.-v.164.-P.735-747.

5. Krizek B.A. Making bigger plants: key regulators of final organ size //Curr. Opin Plant Biol.-2009.-12.-P.17-22.

6. Jaleel, C.A.P., Wahid A., Farooq M., Somasundaram R., Panneerselvam R. Drought stress in plants: a review on morphological characteristics and pigment composition // Int. J. Agric. Biol.-2009.-v.11.-P.100-105.

7. Stitt M., Sulpice R., Keurentjes J. Metabolic networks: how to identify key components in the regulation of metabolism and growth // Plant Physiol.- 2010.-152.P.428-444.

8. Жук О.І. Клітинний ріст в апексі пагона пшениці // Архивариус.-2016.вип.7.-Київ.-С.24-27

9. Жук О.І. Ріст листків пшениці за різного забезпечення мінеральним живленням // Архивариус.- 2016.-вип.6.-Київ.-С.15-18.

10. Жук О.І. Формування адаптивної відповіді рослин на дефіцит води // Физиология и биохимия культ.растений.- 2011.-т.43,№1.-С.26-37.

11. Жук О.І. Ріст міжвузлів пшениці за різних умов мінерального живлення // Modern Phytomorphology.- 2013.- 4.-P.377-381.

12. Жук О.І. Продуктивність рослин пшениці озимої за умов посухи // Фактори експериментальної еволюції організмів.-2018.- т.23.-С.63-67. 